IFN Working Paper No. 828, 2010

\title{
Trade Facilitation and the Extensive Margin
}

\author{
Maria Persson
}




\title{
Trade Facilitation and the Extensive Margin ${ }^{*}$
}

\author{
Maria Persson $^{\dagger}$ \\ Lund University \\ Research Institute of Industrial Economics (IFN)
}

\begin{abstract}
The literature on trade facilitation has mostly focused on implications for trade volumes. However, recent theoretical contributions have emphasized that trade costs - such as transaction costs related to cross-border trade procedures - affect both the traded volumes of "old" goods (the intensive margin) and the range of traded goods (the extensive margin). This paper therefore tests whether trade facilitation affects the extensive margin by counting the number of 8-digit products that are exported from developing to EU countries, and using this as the dependent variable in an estimation. Moreover, it also tests whether the extensive margins in differentiated and homogeneous goods are affected in the same way by transaction costs. Estimation results suggest that if export transaction costs - proxied by the number of days needed to export a good - declined by 1 per cent, the number of exported differentiated and homogeneous products would rise by 0.7 and 0.4 per cent respectively. Policy simulations further illustrate that if all countries were as efficient at the border as the most efficient country at the same level of development, the number of exported differentiated and homogeneous products would increase by 64 and 29 per cent respectively.
\end{abstract}

JEL Classification: C21, F13, O24

Keywords: Trade Facilitation; Extensive Margin; Export Diversification; Differentiated Products; Homogeneous Products; European Union, Developing Countries.

\footnotetext{
* The paper - which is a revised version of Working Paper 2008:13, Department of Economics, Lund University, with the title "Trade Facilitation and the Extensive and Intensive Margins of Trade" - was partly written while the author was visiting the Leverhulme Centre for Research on Globalisation and Economic Policy (GEP) at the University of Nottingham. The author thanks Richard Kneller, Inmaculada Martínez-Zarzoso, Patrik Gustavsson Tingvall, Fredrik Wilhelmsson, Yves Bourdet, Joakim Gullstrand, Karin Olofsdotter, and seminar participants at the Eleventh Annual Conference on Global Economic Analysis in Helsinki, June 2008; the Tenth Annual European Trade Study Group Conference in Warsaw, September 2008 and at Lund University for helpful comments and suggestions. Financial support from the Marianne and Marcus Wallenberg Foundation, and from the Jan Wallander and Tom Hedelius Foundation under research grant numbers P2006-0131:1 and W2009-0352:1 is gratefully acknowledged.

${ }^{\dagger}$ Address: Department of Economics, Lund University. P.O. Box 7082, SE-220 07 Lund, Sweden. E-mail: maria.persson@nek.lu.se; Phone: +46 (0)46 22246 70; Fax: +46 (0)46 2224613.
} 


\section{Introduction}

While establishing that trade facilitation - the issue of cutting red tape at the border - is one of the most interesting and promising current trade policy topics, the existing literature has focused almost exclusively on estimating the extent to which reform of trade procedures would affect aggregated trade volumes. However, although most scholars agree that trade facilitation has a strong potential for increasing trade volumes, little is known about how, i.e. through which mechanisms, trade facilitation affects trade. With reference to the growing theoretical literature on heterogeneous firm trade theory, does trade facilitation simply increase the traded volumes of "old" goods (an effect at the intensive margin) or does it increase the range of traded goods (an effect at the extensive margin)? Further, are all products similarly affected, or does trade in certain types of products stand to benefit more?

Answering these questions is arguably important. First, from a policy perspective, it is useful to establish whether trade facilitation increases trade primarily through the extensive or the intensive margin. If trade grows at the extensive margin, this may be interpreted as export diversification, which in turn has been both theoretically and empirically linked with economic growth (for an overview of studies and a discussion of the theoretical links, see e.g. Herzer and Nowak-Lehmann 2006). Further, the type of good that a country diversifies into is not in itself irrelevant: if trade facilitation promotes exports of differentiated products rather than homogeneous goods, this would generally be seen as a desirable outcome in terms of the development process.

Additional justification for the importance of studying the effects of trade facilitation at the extensive margin, and for allowing different types of goods in the analysis, can be found in recent theoretical developments. In an extension to the heterogeneous firm trade literature, Chaney (2008) derives a model where the extensive and intensive margins' sensitivities to trade barriers depend on the elasticity of substitution, so the extensive margin for differentiated goods is e.g. predicted to be more sensitive to trade barriers than if goods were more homogeneous, while the opposite holds for the intensive margin. In other words, in order to fully understand how trade will react to changes in trade barriers resulting from trade facilitation, it may be necessary to simultaneously take into account both the decomposition of trade into its margins and the degree of differentiation of the traded goods.

At present, the trade facilitation literature contains only limited evidence concerning these matters: Dennis and Shepherd (2007) show that export costs at the border have an effect on the number of goods being exported, and Sadikov (2007), as well as Martínez-Zarzoso and Márquez-Ramos (2008), find evidence that trade facilitation has a stronger impact on the traded volumes of differentiated goods. Hence, the two issues have been examined separately. However, as illustrated by the theoretical model in Chaney (2008), to get a good picture of 
how trade policy changes would affect total trade, it is probably necessary to both decompose trade into extensive and intensive margins and allow various types of products in the analysis.

Focusing on the potential of trade facilitation for North-South trade, this paper therefore asks whether the extensive margins of trade in differentiated and homogeneous goods are affected in the same way by trade transaction costs related to cumbersome crossborder trade procedures. This is done by counting the number of 8-digit products that are exported from developing to EU countries, and then using this number as the dependent variable in an estimation, allowing separate effects for differentiated and homogeneous goods. Trade transaction costs are proxied by the number of days needed to export a good, using data from the World Bank Doing Business Database.

Our empirical findings suggest that countries with large export transaction costs, all else equal, will tend to export fewer goods. The results further indicate that both the number of exported differentiated and the number of exported homogeneous goods are significantly negatively affected by inefficient cross-border trade procedures, but also that the negative effect is stronger for differentiated goods. These results are consistent with the theoretical predictions from Chaney (2008).

The remainder of the paper starts with an outline of a suitable theoretical framework for analyzing the mechanisms through which trade facilitation affects trade. The issue of trade facilitation is then discussed, including how to define and measure it. Thereafter, there is an empirical section, outlining the empirical strategy and presenting estimation results and policy simulations. The last section of the paper summarizes the main results and offers some concluding remarks.

\section{Theoretical Framework}

A natural theoretical setting for linking inefficient cross-border trade procedures to the extensive margin of trade is the emerging literature on heterogeneous firm trade theory, with Melitz (2003) being a seminal contribution. We focus on one interesting extension to this model, Chaney (2008), which allows for many asymmetric countries separated by asymmetric trade barriers. Basically, it is a model of monopolistic competition, but unlike representative firm models such as Krugman (1980), firms are not identical, but differ in the level of productivity, and, in addition, there is a fixed cost of entering the export market.

Referring to Chaney (2008) for a more detailed description, the intuition behind the model is that firms vary by productivity, and because of the existence of fixed and variable costs of exporting, only more productive firms will find it profitable to export. The profitability of exports varies according to destination, so it is more profitable to export to markets with, for example, high demand, low variable trade costs and low fixed costs. For 
every export destination $i$, there is a threshold level of productivity that yields zero profits from exports for firms in country $j$. All firms in $j$ with a higher productivity than this will have positive profits from exporting to $i$. Therefore, only a subset of domestic firms will be exporters, but this subset varies with the characteristics of the foreign market.

Defining the intensive margin as exports per existing exporter and the extensive margin as the set of exporting firms, a reduction in variable trade costs will affect both margins positively, by making each existing exporter export more and increasing the number of exporters, since the threshold productivity level will drop. On the other hand, a reduction in fixed trade costs will not affect the intensive margin (the existing exporters have already paid this cost), but will induce new firms to enter the export market. In other words, it will have a positive effect on the extensive margin.

Chaney (2008) shows in his model that the extensive and intensive margins' sensitivity to trade barriers is affected in opposite directions by the elasticity of substitution. A high elasticity of substitution (homogeneous goods) implies that the intensive margin is fairly sensitive to changes in trade barriers, while the extensive margin is not. As goods become more differentiated (i.e. as the elasticity of substitution decreases), the extensive margin will become more sensitive to trade barriers, whereas the intensive margin will become less sensitive. Thus, a theoretical prediction would be that the effects of trade transaction costs on the extensive margin will be larger in absolute terms for differentiated goods than for homogeneous goods.

\section{Trade Facilitation}

\subsection{Background}

Loosely speaking, trade facilitation is about making it easier for traders to move goods across borders by making cumbersome cross-border trade procedures more efficient. The Doha Ministerial Declaration (WTO 2001), for instance, formally refers to trade facilitation as "expediting the movement, release and clearance of goods, including goods in transit". Inefficient trade procedures constitute costs to traders in several ways, and it may be helpful to think of these costs in terms of being sunk, fixed or variable. Before being able to enter any export market, a potential trader must acquire knowledge about the necessary trade procedures. The more complex these are, the higher the cost for the trader. A firm only has to pay this cost once (unless procedures change), so this may be seen as a one-time sunk cost of entering the market. However, each time that goods are to be sent across the border, all the relevant procedures must be complied with, so even though the firm has paid the sunk market entry cost and knows what to do, it still has to take the time and effort to fill out all relevant forms, collect the required stamps etc. The magnitude of these compliance costs will 
generally not depend on the volume of the shipment, so they may be characterized as fixed, but they will have to be paid each time goods are shipped. Obviously, the more complicated and extensive the rules, the higher the costs of complying with them.

Besides sunk and fixed costs, there may also be variable costs, i.e. costs that depend on the size of the shipment. Such costs are for instance caused by the time delays that inefficient procedures almost inevitably yield. Time delays lead to (particularly - but not only - variable) costs in various ways. Depending on the type of good, there may be depreciation costs - either in terms of physical depreciation or because products quickly lose their market value. Further, long delays will cause unnecessary storage costs, they are associated with increased uncertainty about delivery times, and they may simply leave companies unable to take advantage of business opportunities.

How can such costs be lowered? Concretely, trade facilitation might include reforms such as reducing the number of official documents, signatures and stamps required for exports; standardizing and simplifying required documentation; increasing the possibilities for electronic data submission; publishing all relevant laws, regulations etc. about trade procedures and data requirements; creating a website where all relevant information can be found; implementing audit-based control and risk management and improving the communication between relevant government bodies (see e.g. Hellqvist 2003, Swedish National Board of Trade 2008 or Milner et al. 2008).

\subsection{Previous Research}

So far, the research that has been done to assess the trade effects of trade facilitation has focused on the implications for aggregated trade volumes. All in the gravity tradition, but using various ways to define and measure trade facilitation and to estimate its results, Wilson et al. (2003; 2005), Soloaga et al. (2006), Djankov et al. (2006), Persson (2008), Lee and Park (2007), Nordås et al. (2006) and Iwanow and Kirkpatrick (2007) all tend to find significant effects on trade volumes. However, so far, there is only a very limited amount of research that deals with the effects of trade facilitation on trade decomposed into extensive and intensive margins or for different types of goods.

Dennis and Shepherd (2007) use the number of 8-digit product lines for every twodigit sector exported from developing countries to the EU in 2005 as a measure of export diversification - this being seen as export growth at the extensive margin. Using data from the World Bank's Doing Business Database, they find that export costs, defined as the official fees levied on a 20-foot container leaving the exporting country, have a significantly negative effect on the number of product lines exported in every 2-digit sector. 
Sadikov (2007) makes use of the Doing Business Database to measure trade facilitation-related border barriers as the number of signatures that an exporter has to collect from the authorities to export a good. Bilateral export volumes are then regressed on this as well as other gravity controls, while allowing homogeneous and differentiated goods to have different effects. Sadikov draws the conclusion that export volumes of differentiated products are more sensitive to changes in export signatures than exports volumes of homogeneous goods.

Martínez-Zarzoso and Márquez-Ramos (2008) study the effect of trade facilitation on sectoral non-zero trade volumes in 2000. Including variables from the Doing Business Database, which measure the costs and time involved in exporting and importing, they conclude that export volumes of homogeneous and reference-priced goods are less timesensitive than export volumes of differentiated goods.

\subsection{Data and Sample}

To measure the costs relevant for trade facilitation, we use the number of days needed to export a standardized good as a proxy. The data comes from the World Bank's (2007a) Doing Business Database. In the Trading Across Borders section of this large survey, local freight forwarders, shipping lines, customs brokers and port officials are asked about how much time, documentation and costs would be involved for a hypothetical trading firm to export a welldefined, standardized good. ${ }^{3}$

Using eligibility for the 2005 EU Generalized System of Preferences (GSP) as the definition of being a developing country, we have access to data for 130 developing countries concerning the time needed for exports. ${ }^{4}$ Table 1 shows some descriptive statistics for developing countries. The average time needed to export a good for all developing countries is 34 days, but it actually varies from as low as 9 days in Panama up to a maximum of 102 days in Iraq. For a list of the included countries, as well as data sources and definitions for the other variables, see Tables 5 and 6 in the Appendix.

\footnotetext{
3 The hypothetical trading firm that is a private limited liability company, fully domestically owned with a minimum of 100 employees, is located in the country's most populous city but does not operate within an export processing zone (EPZ) or an industrial estate with special export or import privileges, and exports more than 10 per cent of its sales to international markets. The good is assumed to be non-hazardous, not to include any military arms or equipment, not to require refrigeration or any special environment, nor any special phytosanitary or environmental safety standards, and to be shipped in a dry-cargo, 20-foot, full container load. Trade is assumed to take place by ocean transportation through the closest or main port to the most populous city (the port may be located in another city or country). All procedures from the conclusion of a sales contract until the good leaves the port of exit are included. The database contains data on all documents required for export; the number of days needed, and the official fees levied on the container. For more specifics, see World Bank (2007a), or Djankov et al. (2006).

${ }^{4}$ For a few countries, there is no data for 2005, but data is available for 2006 or 2007 . When this is the case, we choose to use the latter data to get as full a sample as possible. This is reasonable, given that there is very little time-series variation in the data (which implies, also, that nothing is gained from adding more years to the sample).
} 
Table 1. Days Needed for Exports by Developing Countries

\begin{tabular}{lllll}
\hline Country Group & Mean & Min & Max & No. of Obs. \\
\hline Low Income & 43 & 20 & 82 & 51 \\
Lower Middle Income & 31 & 15 & 102 & 50 \\
Upper Middle/High Income & 21 & 9 & 78 & 29 \\
Least Developed & 40 & 20 & 102 & 47 \\
All Developing Countries & 34 & 9 & 130 \\
\hline Source: Author's calculations using data from the World Bank (2007a) Doing Business Database. Note that these figures only \\
include developing country exporters (a few of which will be classified as “high income”).
\end{tabular}

The Doing Business Database has been extensively used in the trade facilitation literature for instance by Dennis and Shepherd (2007) (the costs of exporting), Sadikov (2007) (number of signatures) and Martínez-Zarzoso and Márquez-Ramos (2008) (costs and time of exporting and importing). Popular as it may be, it should be acknowledged that the data is by no means ideal. The arguably most important problem is that there is (in practice) no real time series variation, implying that the researcher must instead rely on the cross-sectional variation between countries. Econometrically, this makes controlling for unobserved heterogeneity much more difficult, and, obviously, it also makes it a lot harder to draw conclusions on causality rather than correlation. Further, the data does not differentiate between products, between different destination or origin countries or between large and small firms. These issues all pose problems for the empirical analysis, but it should be emphasized that no other available data is better on these accounts, and also tend to have poorer geographical coverage. We therefore choose to use this data as an indicator of the fixed and variable costs associated with exporting, while acknowledging that repeating the analysis with improved data in the future will be useful.

It should lastly be noted that, while using the other Doing Business variables for a robustness check, we consider the time variable to be the best way to capture trade transaction costs. The existence of sizeable direct costs for exporting or the need to collect many signatures or fill out many documents is primarily related to the fixed costs of exporting. Long time delays, on the other hand, can be caused by for example the need to collect many signatures, and will therefore capture fixed costs, but delays will, as discussed above, also capture variable costs of exporting. Therefore, the time variable is a much broader indicator, and should be a good proxy for the general effectiveness of cross-border trade procedures, which is what we want to capture.

\section{$4 \quad$ Empirical Analysis}

The extensive margin has received an increasing amount of attention in empirical research over the last the few years. Various methodologies and types of underlying trade data have 
been used to measure and draw conclusions about the extensive margin, but interestingly, irrespective of what kind of dependent variable is being used, most papers employ a set of explanatory variables that by and large can be said to belong to the gravity tradition. ${ }^{5}$

This paper follows, among others, Dennis and Shepherd (2007) and measures the extensive margin by counting the number of products that a country exports. This measure is simple and intuitive, and it corresponds fairly well with the theoretical concepts. It would clearly be an advantage to use variations over time, or product-specific firm-level data. However, there is in practice no such data available on the effectiveness of cross-border trade procedures. Hence, to be able to say something about how these procedures affect the extensive margins of trade, it is necessary to exploit the cross-sectional variation between countries.

As the basis for counting the number of exported products, we use data from Eurostat (2007) for 2005 on imports to EU25 countries at the 8-digit Combined Nomenclature (CN) level from all developing countries with positive exports to at least one EU country. Using these detailed import data to 25 EU countries from 152 developing countries gives us 3,800 country-pairs and almost half a million observations with positive trade flows (in practice, the sample of exporters decreases to 130 countries due to lack of data on export transaction costs). Since we want to be able to test the hypothesis that different types of goods are not affected in the same way by trade transaction costs, we count the number of exported products for both of two types: differentiated and homogeneous, where the classification of goods into different types follows Rauch (1999). ${ }^{6}$ Thus, there are two observations on the extensive margin for every country-pair, yielding 7600 country-pair-type observations in total.

It is important to be clear on how zeroes are to be treated. Eurostat only reports positive trade flows, but, using this to deduce the potential trade flows that are zero, it turns out that about 44 per cent of all (zero and non-zero) observations are such that there are no exports at all from the developing country for this particular type of product. Obviously, these

\footnotetext{
${ }^{5}$ Examples of papers that have used disaggregated country-level trade data to measure the extensive (and sometimes intensive) margin include Dennis and Shepherd (2007), Cadot et al. (2007), Brenton and Newfarmer (2007), Evenett and Venables (2002), Flam and Nordström (2006), Baldwin and Di Nino (2006), Amurgo-Pacheco and Piérola (2008), Debaere and Mostashari (2005), Baldwin and Harrigan (2007), Hummels and Klenow (2005), Funke and Ruhwedel (2001) and Kehoe and Ruhl (2003). Other authors have used aggregated country-level trade data - Felbermayr and Kohler (2006; 2007) and Helpman et al. (2008) - or firm-level trade data: e.g. Bernard and Jensen (2004), Crozet and Koenig (2007), Bernard et al. (2007) and Andersson (2007).

${ }^{6}$ Rauch's classification has been used in many contexts before. In the particular area of trade facilitation, Sadikov (2007) applies the so-called liberal classification, while Martínez-Zarzoso and Márquez-Ramos (2008) use the conservative categorization. For details on the classification, see Table 5 in the Appendix. Note that we use the conservative classification, but results do not change if we switch to the liberal classification. Note further that besides differentiated goods, Rauch distinguishes between two types of homogeneous goods - those that are traded on organized exchanges, and those for which there are reference prices that are quoted in trade publications. Since there does not seem to be a theoretical reason for treating these types of goods differently in the context of the Chaney (2008) model, we refer to both types of goods as homogeneous.
} 
zeroes are very important to include in the investigation, since trade might be absent precisely because trade costs are too high.

\subsection{Descriptive Statistics}

Table 2 suggests some interesting patterns regarding developing countries' trade with the EU. Trade data at the 8-digit product level is very detailed, and still the mean number of products exported in any given bilateral pair is surprisingly low for all income groups: the highest number is 259 products on average for lower middle-income countries. However, looking at the maximum number of products that are exported bilaterally, there is also evidently a great deal of variation. For instance, China exports 5449 products to the United Kingdom, but, at the same time, there is actually no bilateral trade at all for quite a few pairs of countries.

Table 2. Developing Countries' Exports to the EU

\begin{tabular}{lllllllcc}
\hline & \multicolumn{2}{c}{ No. of Products } & \multicolumn{2}{c}{ Unique Products } & \multicolumn{3}{c}{ No. of EU Markets } \\
Country Group & Mean & Max & Mean & Min & Max & Mean & Min & Max \\
\hline Low Income & 106 & 3962 & 506 & 25 & 6038 & 19 & 9 \\
Lower Middle Income & 259 & 5449 & 1194 & 12 & 7512 & 21 & 5 & 25 \\
Upper Middle/High Income & 165 & 2476 & 917 & 7 & 5407 & 19 & 2 & 25 \\
Least Developed & 30 & 589 & 225 & 25 & 1186 & 17 & 6 & 25 \\
All Developing Countries & 181 & 5449 & 871 & 7 & 7512 & 20 & 2 & 25 \\
\hline
\end{tabular}

Note: Author's calculations using data from Eurostat (2007). Note that only developing countries' exports to the EU are included: due to the definition of a developing country (GSP eligible), this will include some high income countries. The first two columns show the number of 8-digit products that are exported per bilateral pair. Unique products refers to the number of products that a developing country exports to any EU country. The last three columns show the number of EU markets the country exports to.

Looking at unique products as well, i.e. the number of individual products that countries export to at least one EU country, the averages are a lot higher than the bilateral measures for all income groups. The average for all developing countries is 871 products, to be compared with 181 for any given bilateral pair. This suggests that while many countries have some exports to most EU countries (the average developing country exports to $20 \mathrm{EU}$ markets), most of this trade takes place with only a few main trading partners, while the number of products exported to the rest is much lower.

As shown in Table 3, for all country groups, the majority of all exports is in differentiated goods. However, while homogeneous goods represent only about 22 per cent of all goods that are exported, this trade corresponds to about 44 per cent of the value of exports: in other words, the bilateral flows of homogeneous goods tend to represent relatively large values. 
Table 3. Developing Countries’ Exports by Type of Product

\begin{tabular}{|c|c|c|c|c|c|c|}
\hline \multirow[b]{2}{*}{ Country Group } & \multicolumn{3}{|c|}{ Homogeneous Products } & \multicolumn{3}{|c|}{ Differentiated Products } \\
\hline & Average EM & Share Value & Share EM & Average EM & Share Value & Share EM \\
\hline Low Income & 20 & 0.47 & 0.26 & 80 & 0.53 & 0.74 \\
\hline Lower Middle Income & 47 & 0.47 & 0.22 & 200 & 0.53 & 0.78 \\
\hline Upper Middle/High Income & 34 & 0.38 & 0.17 & 118 & 0.62 & 0.83 \\
\hline Least Developed & 6 & 0.43 & 0.24 & 23 & 0.57 & 0.76 \\
\hline All Developing Countries & 35 & 0.44 & 0.22 & 135 & 0.56 & 0.78 \\
\hline
\end{tabular}

Note: Author's calculations using data on EU import flows from Eurostat (2007). For the types of products respectively, and for various country groups, figures show the average number of products (extensive margin: $E M$ ) being exported bilaterally, as well as the shares of the bilateral import value and numbers of products that can be attributed to the various types of goods. Note that only non-zero trade is used for these calculations.

\subsection{Estimation}

The extensive margin is empirically measured by counting the number of exported products for every type, i.e. the dependent variable takes the form of non-negative count data. Thus, using a linear model for $\mathrm{E}(E M \mid \mathbf{x})$ would be inappropriate, since this could yield negative predicted values. Instead, a Poisson estimation strategy is used (see Wooldridge 2002). ${ }^{7}$ It is assumed that

$$
\mathrm{E}(E M \mid \mathbf{x}) \boldsymbol{\beta} \exp (\mathbf{x})
$$

where $\mathbf{x}$ is a $1 \times K$ vector of explanatory variables to be described below, and the vector $\boldsymbol{\beta}$ is $K \times 1$.

The choice of explanatory variables to include in $\mathbf{x} \boldsymbol{\beta}$ resembles that made in the rest of the literature on the extensive margin.

$$
\begin{aligned}
\mathbf{x \beta}_{j}= & \beta_{1}+\beta_{2} \ln \left(T F_{j}\right)+\beta_{3} \ln \left(d_{i j}\right)+\beta_{4} \text { border }_{i j}+\beta_{5} \text { lang }_{i j}+ \\
& \beta_{6} \text { colony }_{i j}+\beta_{7} \text { landl }_{j}+\beta_{8} \ln \left(Y_{j}\right)+\beta_{9} \ln \left(P_{j}\right)+\beta_{10} L D C_{j} \\
& +\beta_{11} \ln \left(1+\text { tariff }_{i j}\right)+\beta_{12} \text { remote }_{j}+\beta_{13} \text { diff }_{s}+\mu_{i}
\end{aligned}
$$

For future reference, we will refer to this as Model I. The vector of variables explaining the extensive margin of exports to importing EU country $i$ from the exporting developing country $j$ of product type $s$ includes first and foremost the level of export transaction costs related to the efficiency of the cross-border trade procedures in the exporting country. This is labelled $T F_{j}$. We use the number of days needed to export a good across the border as a proxy for

\footnotetext{
${ }^{7}$ Estimated using STATA’s poisson command, with robust standard errors, clustered by country-pairs.
} 
export transaction costs. Besides these costs related to cross-border trade procedures, the distance $d_{i j}$ between the two countries' capitals is included as a proxy for variable transportation costs. Further, we include indicator variables for sharing a common border, border $_{i j}$, the same language, lang $_{i j}$, or a joint colonial history, colony $y_{i j}$. These are variables that influence the ease with which new trading relationships can be created, so with reference to the theoretical model they primarily affect the level of fixed costs. We also control for whether the exporter is landlocked (landl $)_{j}$, a geographical factor known to increase transportation costs. The model includes the exporting country's GDP $\left(Y_{j}\right)$ and population $\left(P_{j}\right)$ to control for supply capacity. ${ }^{8}$ As a further control for the level of development and supply side conditions, there is a dummy $\left(L D C_{j}\right)$ controlling for whether the exporter is a least developed country, and we control for the average tariff country $j$ exporters face when exporting to country $i$, tariff $f_{i j}$, and for the exporting country's level of remoteness ( remote $_{i j}$ ).

The model includes a dummy variable, diff, equal to one if the observation refers to the number of differentiated goods, and zero otherwise. Since the dependent variable is the number of exported homogeneous and differentiated products, this is important because there are many more differentiated than homogeneous products. Lastly, because the paper focuses on export activities, we have chosen not to include importer characteristics such as the level of trade transaction costs in the importing country. Instead, the model includes importer fixed effects, $\mu_{i}$, which control for all observable and unobserved importer specific heterogeneity (including trade transaction costs, GDP etc). ${ }^{9}$

The model above can be used to measure the average effect of trade transaction costs. However, the main innovation of the paper is to measure these effects separately for homogeneous and differentiated goods, so the model has to be augmented somewhat to be able to do this. Defining the vector $\mathbf{z}$ to consist of all explanatory variables except the ones measuring the trade transaction costs, Model II is given by

$$
\mathbf{x} \boldsymbol{\beta}_{j}=\delta_{1} d i f f_{s} * \ln \left(T F_{i j}\right)+\delta_{2} \text { homo }_{s} * \ln \left(T F_{i j}\right) \neq \boldsymbol{\alpha} .
$$

So, the variable measuring export transaction costs is now interacted with dummies for differentiated (diff) or homogeneous (homo) goods, allowing these two types of goods to have separate parameters.

\footnotetext{
${ }^{8}$ Empirically, Imbs and Wacziarg (2003) have illustrated that diversification follows a U-shaped pattern, where countries first diversify when income per capita levels rise, but then start to specialize again at a later stage in the development process. Cadot et al. (2007) find the same pattern concerning export diversification. Concerning this, note that the inclusion of GDP and population means that we are de facto controlling for income per capita.

${ }^{9}$ Including country-specific exporter effects is appealing, but they would capture everything that only varies by exporter, i.e. one could not measure the effect of cumbersome cross-border trade procedures separately. See Table 5 in the Appendix for all variable definitions and data sources.
} 


\subsection{Empirical Results}

The results of a Poisson estimation of Models I and II are presented in the first two columns of Table 7 in the Appendix. In Model I, all the observations are pooled together. The estimation shows that, all else equal, countries with high export transaction costs, i.e. countries with long border delays, will export significantly fewer products. The coefficient can be interpreted as an elasticity, so decreasing border delays by 1 per cent will increase the number of exported products by about 0.61 per cent. This corresponds fairly well with the findings in Dennis and Shepherd (2007). These authors, while using a slightly different setup - for instance they use a different measure for trade transaction costs: the official costs of exporting $^{10}$ - find an elasticity of -0.32 .

In Model II, the specification has been made less restrictive by allowing homogeneous and differentiated goods to have different coefficients. This leads to some interesting results. First, as expected, differentiated and homogeneous goods both have negative and highly significant coefficients for trade transaction costs. In other words, all else equal, countries with inefficient border procedures tend to export fewer differentiated and homogeneous goods. Second, the coefficient for differentiated products is significantly more negative than the corresponding coefficient for homogeneous goods. This suggests that, just as predicted by the theoretical model, differentiated goods are more sensitive to these kinds of barriers, and countries with long border delays will particularly tend to export fewer differentiated products. Thus, although one must be careful not to draw too strong causal conclusions given that there is only cross-sectional evidence at hand, the results are certainly consistent with the theoretical predictions in Chaney (2008).

It may also be interesting to say a few words about the other explanatory variables. Distance, proxying for variable transport costs, has the expected negative and significant coefficient. Sharing a border, or having a joint colonial history both have a significantly positive effect on the extensive margin. This is as expected, since these are factors that influence the ease with which new trading relationships are created. More surprisingly, however, there is no evidence that two countries sharing the same language will trade a larger number of products: the coefficient is insignificant. The coefficient for landlockedness is significant and negative, while the coefficients for GDP and population are significant and positive. The dummy controlling for whether the exporter is an LDC or not also has a significant and negative coefficient. Lastly, the EU tariff level has a positive and significant coefficient, which is not what one would expect, and the variable measuring remoteness is insignificant.

\footnotetext{
${ }^{10}$ They also use a different sample (for instance they use aggregate EU imports) and calculate the number of exported products per 2-digit sector.
} 


\subsection{Policy Simulations}

From a policy perspective, the issue of the relationship between inefficient border procedures and the extensive margin boils down to the question: "How many more products would a country export if it were to engage in trade facilitation reform?”. Given the sort of data that is available at present - cross-sectional data that only rather crudely proxies the efficiency of cross-border trade procedures, and that prevents the use of estimation methods where one could more properly control for unobserved heterogeneity across exporting countries - one should be very cautious when interpreting the estimation results as causal relationships. Therefore, using the estimated parameters to simulate what the effects would be of reducing border delays can at best only be seen as an illustrative exercise. However, it does offer an intuitive understanding of what the data and estimation results might actually be telling us, so remembering that the figures should not be taken too literally, we have considered two reform scenarios.

Table 4. Policy Simulations: Trade Facilitation's Effects on Exports

\begin{tabular}{|c|c|c|c|c|c|c|c|}
\hline & \multirow[b]{3}{*}{ Income Group } & \multirow{2}{*}{\multicolumn{3}{|c|}{$\begin{array}{l}\text { Scenario } 1 \\
\text { 5-day reduction }\end{array}$}} & \multicolumn{3}{|c|}{ Scenario 2} \\
\hline & & & & & \multicolumn{3}{|c|}{ Best practice within income group } \\
\hline & & Per cent & Products & $\begin{array}{l}\text { Exp. } \\
\text { Relations }\end{array}$ & Per cent & Products & $\begin{array}{l}\text { Exp. } \\
\text { Relations }\end{array}$ \\
\hline \multirow[t]{5}{*}{ Differentiated goods } & Low Income & 10 & 12 & 284 & 65 & 57 & 1283 \\
\hline & Lower Middle Income & 16 & 54 & 1330 & 57 & 94 & 2242 \\
\hline & Upper Middle/High Income & 25 & 57 & 1394 & 74 & 205 & 4986 \\
\hline & Least Developed & 11 & 5 & 91 & 63 & 28 & 564 \\
\hline & All Developing Countries & 15 & 38 & 934 & 64 & 104 & 2478 \\
\hline \multirow[t]{5}{*}{ Homogeneous goods } & Low Income & 5 & 2 & 32 & 30 & 6 & 135 \\
\hline & Lower Middle Income & 8 & 7 & 161 & 26 & 11 & 249 \\
\hline & Upper Middle/High Income & 13 & 6 & 143 & 33 & 23 & 551 \\
\hline & Least Developed & 6 & 1 & 8 & 29 & 3 & 39 \\
\hline & All Developing Countries & 8 & 5 & 106 & 29 & 12 & 269 \\
\hline
\end{tabular}

In the first scenario, there is a uniform reduction of border delays by five days for all countries. For most countries, this corresponds to a fairly realistic reform. As shown in Table 4, all else equal, this can be expected to increase the number of exported differentiated products by an average of 15 per cent, with income group averages ranging from 10 to 25 per cent. The number of exported homogeneous products would increase by 5 to 13 per cent. Translated into actual products, this means that a typical developing country would export an extra 38 differentiated or 5 homogeneous products in any given bilateral trade relationship. 
Since most developing countries export to many EU countries, as illustrated in the column Exp.Relation, if this number is multiplied by the number of EU markets that an export country serves, this scenario would on average lead to an additional 934 export relationships in differentiated goods for every exporter, or 106 new export relationships in homogeneous goods (where an export relationship is defined as one product that is exported to one market). Note that these are actually conservative estimates of the number of new export relationships, since trade facilitation may also make it possible for countries to export to new markets.

In Scenario 2, through trade facilitation, all countries reach the same level of border delays as the country with the lowest level of delays within their own income group. Of course, unlike Scenario 1, this is not a realistic outcome. However, since it takes as its point of reference the level of border delays that the most ambitious countries at various income levels have actually achieved, it offers a sort of "best case" scenario, and illustrates what could reasonably be gained if countries made trade facilitation their priority. The changes needed in an individual country will depend on its initial level of delays, so those that currently have the largest problems will be expected to change the most, while the countries with best practice are assumed to temporarily have exhausted their reform possibilities.

In this "best case" scenario, the number of exported differentiated products would on average increase by 64 per cent, while the number of homogeneous products would increase by 29 per cent. In other words, if all countries were as efficient at the border as the most efficient country at the same level of development, every bilateral North-South trade relationship would be diversified by an extra 104 differentiated and 12 homogeneous products. Taking multiple export markets into account, the average developing country would have almost 2500 extra differentiated export relationships, with roughly twice that figure for upper middle- and high-income developing countries. The corresponding figure regarding homogeneous products would be 269 new export relationships.

\subsection{Robustness}

The results have been submitted to a number of robustness checks. As shown in Table 7 in the Appendix, we estimate the model using alternative estimation methods. The most common alternative to the Poisson model is the Negative Binomial model, which is less restrictive, since it does not assume that the mean equals the variance. We also employ zero-inflated Poisson and zero-inflated Negative Binomial models, where non-zero and zero outcomes have different probability models (see Greene 2008). Further, long border delays could be the result of large trade flows, which in turn could result indirectly from many exported products. To investigate whether such endogeneity influences the results, we estimate the model using a Poisson GMM estimator which allows endogenous variables to be instrumented by excluded 
variables - see Mullahy (1997) and Nichols (2007). The official costs of exporting and the number of documents required, both variables originating from the Doing Business Database, are used as instruments for trade transaction costs. Moreover, since it is not possible to explicitly control for unobserved exporter heterogeneity by fixed effects in the baseline specification, as an alternative, we try estimating a Poisson model with exporter random effects. We also, lastly, estimate the model with a simple OLS regression. Reassuringly, in all cases, but one, the conclusions remain the same. The only exception is that while both differentiated and homogeneous products consistently have negative coefficients (and the former coefficient always is larger in absolute terms), in the Poisson estimation with exporter random effects, the coefficient is only significant for differentiated goods.

Having established that the results are generally robust to several other estimation methods, we also check whether different samples or the inclusion of additional covariates makes a difference. Estimation results are displayed in Table 8. First, to see whether bilateral trade relationships that involve very few or no products influence the results, we exclude in three steps all observations where the number of exported products is zero or less than ten or less than 50. Second, we add an index over how well corruption is perceived to be controlled (a factor clearly related to the subject of efficient cross-border trade procedures); a control for the cost of entering the domestic market (following Dennis and Shepherd 2007); and the share of agriculture in GDP or the revealed comparative advantage (RCA) for the agricultural or mining industries as controls for comparative advantage. The coefficients for both types of goods are remarkably stable, and always significantly negative.

Lastly, we allow different coefficients for low- and middle/high-income exporters. Interestingly, as can be seen in Table 8, we again find the negative coefficients of a similar magnitude for both types of goods, but the low-income exporters seem to experience even larger negative effects than middle/high income developing countries. So, to summarize, the result are robust to several alternative estimation methods, different samples of trade and exporting countries and the inclusion of additional control variables.

\section{$5 \quad$ Summary and Conclusions}

Focusing on the potential of trade facilitation for North-South trade, this paper investigates whether the extensive margins of trade in differentiated and homogeneous goods are affected in the same way by trade transaction costs related to cumbersome cross-border trade procedures. This is done by counting the number of 8-digit products that are exported from developing to EU countries, and then using this number as the dependent variable in an estimation, allowing separate effects for differentiated and homogeneous goods. Trade transaction costs are proxied by the number of days needed to export a good, using data from 
the World Bank Doing Business Database. The theoretical model in Chaney (2008) is used to derive the hypothesis that while the extensive margin for both differentiated and homogeneous goods will be negatively affected by cumbersome cross-border trade procedures, the negative effect should be stronger for differentiated goods.

Our empirical findings suggest that countries with large export transaction costs, all else equal, will tend to export fewer goods. The results further indicate that both the number of exported differentiated and the number of exported homogeneous goods are significantly negatively affected by inefficient cross-border trade procedures, but also that the negative effect is stronger for differentiated goods. Estimation results suggest that if export transaction costs declined by 1 per cent, the number of exported differentiated goods would rise by 0.7 per cent, and the number of homogeneous goods would increase by 0.4 per cent. Hence, while the lack of time-series variation prevents us from drawing any strong causal conclusions, the results are certainly consistent with the theoretical predictions.

Policy simulations further illustrate that if all developing countries engaged in trade facilitation so that a uniform reduction of border delays by five days was reached, the average developing country would export an extra 15 per cent differentiated products and 8 per cent homogeneous products to any given EU importer. This might be viewed as a realistic outcome. Given a more ambitious - "best-case" - reform scenario, leaving all countries as efficient at the border as the most efficient country at the same level of development, the number of exported differentiated and homogeneous products would on average increase by 64 and 29 per cent respectively.

Hence, while again emphasizing the caution against drawing too strong conclusions from purely cross-sectional evidence, results do indicate that even a "realistic" reform scenario would have positive effects on the extensive margin, implying that developing countries' exports would become more diversified. In a "best case" scenario, which is realistic in the sense that it builds on what countries at different levels of development have actually achieved today, but still quite ambitious, reforming countries would achieve a much more diversified export structure.

To conclude, we find evidence that trade facilitation has effects on the extensive margin of trade, and therefore affects the range of goods that can be traded. We also find, however, that this effect is not uniform across products: differentiated products are more sensitive than homogeneous products to this type of trade barrier and would therefore respond more strongly to reform aimed at achieving more efficient trade procedures. Interestingly, not only is the elasticity itself stronger for differentiated goods, but as illustrated by the policy simulations, translated into actual traded products, the results are much larger for differentiated goods. 
Hence, a policy oriented interpretation of our results could be that countries with inefficient and bureaucratic border procedures will run the risk of having no choice but to export a small range of products, most of them homogeneous. On the other hand, as highlighted in the policy simulations, countries engaging in reform could expect not only to get a more diversified export by increasing the total number of exported products, but also to have their export consist of differentiated goods to a larger extent, since these are the products that respond strongly to reform. In other words, the earlier discussion of the benefits of trade facilitation, focusing on the magnitude of trade volume increases, may have missed some additional - potentially important - benefits. Exports may not only grow, but also become more diversified, which, it is often argued, has its own benefits for developing countries. Also, trade facilitation would remove at least one of the obstacles to exporting the sort of differentiated products that many developing countries lack in their exports today.

\section{References}

Amurgo-Pacheco, A. and M. D. Piérola (2008), 'Patterns of Export Diversification in Developing Countries: Intensive and Extensive Margins’, World Bank Policy Research Paper No. 4473 (Washington, D.C.: World Bank).

Andersson, M. (2007), 'Entry Costs and Adjustments on the Extensive Margin - An Analysis of How Familiarity Breeds Exports', CESIS Working Paper No. 81 (Stockholm: Royal Institute of Technology).

Baldwin, R. and V. Di Nino (2006), 'Euros and Zeros: The Common Currency Effect on Trade in New Goods’, NBER Working Paper No. 12673 (Cambridge, Massachusetts: National Bureau of Economic Research).

Baldwin, R. and J. Harrigan (2007), 'Zeros, Quality and Space: Trade Theory and Trade Evidence', NBER Working Paper No. 13214 (Cambridge, Massachusetts: National Bureau of Economic Research).

Bernard, A. B. and J. B. Jensen (2004), 'Entry, Expansion, and Intensity in the US Export Boom, 19871992, Review of International Economics, 12, 4, 662-675.

Bernard, A. B., J. B. Jensen, S. J. Redding and P. K. Schott (2007), 'Firms in International Trade', Journal of Economic Perspectives, 21, 3, 105-130.

Bouët, A., Y. Decreux, L. Fontagné, S. Jean and D. Laborde (2008), 'Assessing Applied Protection across the World', Review of International Economics, 16, 5, 850-863.

Brenton, P. and R. Newfarmer (2007), 'Watching More Than The Discovery Channel: Export Cycles and Diversification in Development', World Bank Policy Research Working Paper No. 4302 (Washington, D.C.: World Bank).

Cadot, O., C. Carrère and V. Strauss Kahn (2007), 'Export Diversification: What's Behind the Hump?', CEPR Discussion Paper No. 6590 (London: Centre for Economic Policy Research).

Carrère, C. (2006), 'Revisiting the Effects of Regional Trade Agreements on Trade Flows with Proper Specification of the Gravity Model’, European Economic Review, 50, 2, 223-247.

CEPII (2006), 'Distances', http://www.cepii.fr/anglaisgraph/bdd/distances.htm (Paris: Centre d'Etudes Prospectives et d'Informations Internationales).

CEPII (2007), 'HS2 Aggregation: Applied rates from MAcMap HS6 v1.1 and Bound Tariffs', http://www.cepii.fr/anglaisgraph/bdd/macmap/form_macpmap/download.asp (Paris: Centre d'Etudes Prospectives et d'Informations Internationales).

Chaney, T. (2008), 'Distorted Gravity: The Intensive and Extensive Margins of International Trade', American Economic Review, 98, 4, 1707-1721.

Crozet, M. and P. Koenig (2008), 'Structural Gravity Equations with Intensive and Extensive Margins', CEPII Working Paper No. 2008-30 (Paris: Centre d'Etudes Prospectives et d'Informations Internationales). 
Debaere, P. and S. Mostashari (2005), 'Do Tariffs Matter for the Extensive Margin of International Trade? An Empirical Analysis’, CEPR Discussion Paper No. 5260 (London: Centre for Economic Policy Research).

Dennis, A. and B. Shepherd (2007), 'Trade Costs, Barriers to Entry, and Export Diversification in Developing Countries’, World Bank Policy Research Working Paper No. 4368 (Washington, D.C.: World Bank).

Djankov, S., C. Freund and C. S. Pham (2006), ‘Trading on Time’, World Bank Policy Research Working Paper No. 3909 (Washington, D.C.: World Bank).

Eurostat (2007) Comext Database. http://epp.eurostat.ec.europa.eu/. (Luxembourg: Eurostat). Data downloaded October 2007.

Evenett, S. J. and A. J. Venables (2002), 'Export Growth in Developing Countries: Market Entry and Bilateral Trade Flows’, mimeo, http://www.alexandria.unisg.ch/Publikationen/22177.

Felbermayr, G. J. and W. Kohler (2006), 'Exploring the Intensive and Extensive Margins of World Trade', Review of World Economics, 142, 4, 642-674.

Felbermayr, G. J. and W. Kohler (2007), 'Does WTO Membership Make a Difference at the Extensive Margin of World Trade?', CESifo Working Paper No. 1898. (Munich: Center for Economic Studies (CES), the Ifo Institute for Economic Research and the CESifo GmbH (Munich Society for the Promotion of Economic Research)).

Feenstra, R. C. (1996), 'U.S. Imports 1972-1994: Data and Concordances’, NBER Working Paper No. 5515 (Cambridge, Massachusetts: National Bureau of Economic Research). Data at http://cid.econ.ucdavis.edu/usixd/wp5515d.html.

Feenstra, R. C. and H. L. Kee (2007), 'Trade Liberalisation and Export Variety: A Comparison of Mexico and China', World Economy, 30, 1, 5-21.

Flam, H. and H. Nordström (2006), 'Euro Effects on the Intensive and Extensive Margins of Trade', CESifo Working Paper No. 1881. (Munich: Center for Economic Studies (CES), the Ifo Institute for Economic Research and the CESifo GmbH (Munich Society for the Promotion of Economic Research)).

Funke, M. and R. Ruhwedel (2001), 'Product Variety and Economic Growth: Empirical Evidence for the OECD Countries', IMF Staff Papers, 48, 2, 225-242.

Greene, W. H. (2008), Econometric Analysis, Sixth Edition (Upper Saddle River, New Jersey, US: Pearson Prentice Hall).

Hellqvist, M. (2003), Trade Facilitation from a Developing Country Perspective (Stockholm: SWEPRO/National Board of Trade)

Helpman, E., M. J. Melitz and Y. Rubinstein (2008), 'Estimating Trade Flows: Trading Partners and Trading Volumes’, Quarterly Journal of Economics, 123, 2, 441-487.

Herzer, D. and F. Nowak-Lehmann D. (2006), 'What does Export Diversification do for Growth? An Econometric Analysis', Applied Economics, 38, 15, 1825-1838.

Hummels, D. and P. J. Klenow (2005), 'The Variety and Quality of a Nation's Trade', American Economic Review, 95, 3, 704-723.

Imbs, J. and R. Wacziarg (2003), 'Stages of Diversification', American Economic Review, 93, 1, 63-86.

Iwanow, T. and C. Kirkpatrick (2007), 'Trade Facilitation, Regulatory Quality and Export Performance', Journal of International Development, 19, 6, 735-753.

Kehoe, T. J. and K. J. Ruhl (2003), 'How Important is the New Goods Margin in International Trade?', Research Department Staff Report No. 324 (Minneapolis, Minnesota: Federal Reserve Bank of Minneapolis).

Krugman, P. (1980), 'Scale Economies, Product Differentiation and the Pattern of Trade', American Economic Review, 70, 5, 950-959.

Lee, H. and I. Park (2007), 'In Search of Optimised Regional Trade Agreements and Applications to East Asia’, World Economy, 30, 5, 783-806.

Martinez-Zarzoso, I. and L. Márquez-Ramos (2008), 'The Effect of Trade Facilitation on Sectoral Trade’, B.E. Journal of Economic Analysis \& Policy, 8, 1, Article 42.

Melitz, M. J. (2003), 'The Impact of Trade on Intra-Industry Reallocations and Aggregate Industry Productivity’, Econometrica, 71, 6, 1695-1725.

Milner, C., O. Morrissey and E. Zgovu (2008), 'Trade Facilitation in Developing Countries', CREDIT Research Paper No. 08/05 (Nottingham: Centre for Research in Economic Development and International Trade).

Mullahy, J. (1997), 'Instrumental-Variable Estimation of Count Data Models: Applications to Models of Cigarette Smoking Behaviour', Review of Economics and Statistics, 79, 4, 586-593.

Nichols, A. (2007), 'Ivpois: Stata module for IV/GMM Poisson regression', http://ideas.repec.org/c/boc/bocode/s456890.html. 
Nordås, H. K., E. Pinali and M. Geloso Grosso (2006), 'Logistics and Time as a Trade Barrier’, OECD Trade Policy Working Paper No. 35 (Paris: Organisation for Economic Co-operation and Development).

Papke, L. E. and J. M. Wooldridge (1996), 'Econometric Methods for Fractional Response Variables with an Application to 401(K) Plan Participation Rates', Journal of Applied Econometrics, 11, 6, 619-632.

Persson, M. (2008), 'Trade Facilitation and the EU-ACP Economic Partnership Agreements', Journal of Economic Integration, 23, 3, 518-546.

Rauch, J. E (1999), 'Networks versus Markets in International Trade', Journal of International Economics, 48, 1, 7-35.

Sadikov, A. (2007), 'Border and Behind-the-Border Trade Barriers and Country Exports', IMF Working Paper No. 07/292. (Washington, D.C.: International Monetary Fund)

Soloaga, I., J. S. Wilson and A. Mejía (2006), 'Moving Forward Faster: Trade Facilitation Reform and Mexican Competitiveness’, World Bank Policy Research Working Paper No. 3953 (Washington, D.C.: World Bank).

Swedish National Board of Trade (2008), Trade Facilitation and Swedish Experiences, (Stockholm: Swedish National Board of Trade.

Transparency International (2006), Corruption Perceptions Index, http://www.icgg.org/ (Berlin: Transparency International).

United Nations Statistics Division (2008), SITC Rev.3-HS2002 Correspondances, http://unstats.un.org/unsd/cr/registry/regdnld.asp?Lg=1. (New York: United Nations Statistics Division).

Wilson, J. S., C. L. Mann and T. Otsuki (2003), 'Trade Facilitation and Economic Development: A New Approach to Quantifying the Impact', World Bank Economic Review, 17, 3, 367-389.

Wilson, J. S., C. L. Mann and T. Otsuki (2005), 'Assessing the Benefits of Trade Facilitation: A Global Perspective', World Economy, 28, 6, 841-71.

Wooldridge, J. M. (2002), Econometric Analysis of Cross Section and Panel Data, (Cambridge, Massachusetts: MIT Press)

World Bank (2007a), Doing Business Database, http://www.doingbusiness.org/ExploreTopics/TradingAcrossBorders/ (Washington D.C.: World Bank) Data downloaded October 15, 2007.

World Bank (2007b), World Development Indicators Online (Washington D.C.: World Bank)

WTO (2001) Ministerial Conference, Fourth Session, Doha, 9-14 November 2001, 'Ministerial Declaration', WT/MIN(01)/DEC/1, 20 November (Geneva: World Trade Organization). 


\section{Appendix}

Table 5. Variables and Data Sources

Imports


Export Transaction
$\quad$ Cost (TF)
Distance
Border Common Language
Colony
Landlocked
GDP
Population
LDC
Tariff

Rauch Classification

Export Documents

Export Costs

Control of Corruption Domestic Market Entry Cost Share of Agriculture in GDP

RCA

Remoteness 8-digit (Combined Nomenclature) imports from the Eurostat (2007) Comext Database. Until the 6digit level, the CN classification is the same as the Harmonized System (HS) classification. Since the CN chapter 99 is not included in the HS classification, we have removed this chapter (this means disregarding 760 observations out of nearly half a million). Keeping only the goods that are classified by Rauch (1999) implies that an additional 35,430 observations are deleted.

Time needed to export a good across the border. Data from the World Bank (2007a) Doing Business Database.

Distance in kilometres between capital cities from CEPII (2006).

Importer and exporter share a common border. From CEPII (2006).

CEPII (2006).

Importer and exporter have been in a colonial relationship. From CEPII (2006).

CEPII (2006).

World Bank (2007b) World Development Indicators (WDI).

World Bank (2007b) World Development Indicators (WDI).

Country is a least developed country.

Average applied tariff, calculated using data at the HS2 level from the MAcMap Database, CEPII (2007). See also Bouët et al. (2004).

Dummy variables indicating whether the good is classified as homogeneous or differentiated by Rauch (1999). Data on the Rauch Classification (revised July 2007), at the 4-digit (SITC Rev. 2) level from “John Haveman's International Trade Data” at

http://www.macalester.edu/research/economics/page/haveman/trade.resources/tradedata.html.

Concordances between SITC Rev.2 and Rev. 3 from Feenstra (1996). Concordances between SITC

Rev. 3 and HS from the United Nations Statistics Division (2008).

Alternative measure of export transaction costs: The number of all documents needed to export a good across the border. Data from the World Bank (2007a) Doing Business Database.

Alternative measure of export transaction costs: The costs associated with all the procedures required to export a good across the border. Data from the World Bank (2007a) Doing Business Database.

Data from the Transparency International (2006) Corruption Perceptions Index.

The official cost of registering a firm in per cent of per capita income. Data from the World Bank (2007a) Doing Business Database.

World Bank (2007b) World Development Indicators (WDI).

Revealed Comparative Advantage calculated as $R C A=(X-M) /(X+M)$, where $X$ is exports in a given industry, and $M$ is imports. RCA is calculated for agriculture (HS chapters 1-24) and minerals (HS chapters 25-43), using aggregate EU trade with the developing country.

Following Carrère (2006). Calculated for each exporter $j$ as $R_{j}=\left(\sum_{k=1, k \neq j}^{N} Y_{k}\left(d_{k j}\right)^{1-\sigma}\right)^{1 /(1-\sigma)}$,

where $N$ contains all countries in the world, and $\sigma=4$.

Note: All data are for 2005 unless otherwise stated.

Table 6. Sample of Exporters

\begin{tabular}{ll}
\hline Exporting Region & Country \\
\hline West Africa & Benin, Burkina Faso, Cape Verde, Côte d'Ivoire, Gambia, Ghana, Guinea, Guinea-Bissau, Liberia, \\
& Mali, Mauritania, Niger, Nigeria, Senegal, Sierra Leone, Togo \\
Central Africa & Cameroon, Central African Republic, Chad, Congo Dem. Rep., Congo Rep., Equatorial Guinea, \\
& Gabon, São Tomé and Principe \\
Eastern and Southern & Burundi, Comoros, Djibouti, Eritrea, Ethiopia, Kenya, Madagascar, Malawi, Mauritius, Rwanda, \\
\multicolumn{1}{c}{ Africa } & Seychelles, Sudan, Uganda, Zambia, Zimbabwe \\
Southern Africa & Angola, Botswana, Lesotho, Mozambique, Namibia, South Africa, Swaziland, Tanzania \\
Caribbean & Antigua and Barbuda, Belize, Dominica, Dominican Republic, Grenada, Guyana, Haiti, Jamaica, \\
& St. Lucia, St. Vincent and the Grenadines, Suriname, Trinidad and Tobago \\
Pacific & Fiji, Kiribati, Marshall Islands, Micronesia, Palau, Papua New Guinea, Samoa, Solomon Islands, \\
& Tonga, Vanuatu \\
South Asia & Afghanistan, Bangladesh, Bhutan, India, Maldives, Nepal, Pakistan, Sri Lanka \\
East and South-East Asia & Brunei Darussalam, Cambodia, China, Indonesia, Lao PDR, Malaysia, Mongolia, Philippines, \\
& Thailand, Timor-Leste, Vietnam \\
Eastern Europe and & Armenia, Azerbaijan, Belarus, Georgia, Kazakhstan, Kyrgyz Republic, Moldova, Russian \\
$\quad$ Central Asia & Federation, Tajikistan, Ukraine, Uzbekistan \\
Middle East & Iran, Iraq, Kuwait, Oman, Saudi Arabia, United Arab Emirates, Yemen \\
Mediterranean & Algeria, Egypt, Jordan, Lebanon, Morocco, Syrian Arab Republic, Tunisia \\
Latin America & Argentina, Bolivia, Brazil, Chile, Colombia, Costa Rica, Ecuador, El Salvador, Guatemala, \\
& Honduras, Mexico, Nicaragua, Panama, Paraguay, Peru, Uruguay, Venezuela
\end{tabular}


Table 7. Estimation Results

\begin{tabular}{|c|c|c|c|c|c|c|c|c|}
\hline & Poisson & Poisson & $\begin{array}{l}\text { Negative } \\
\text { Binomial }\end{array}$ & $\begin{array}{l}\text { Zero- } \\
\text { Inflated } \\
\text { Poisson } \\
\end{array}$ & $\begin{array}{l}\text { Zero- } \\
\text { Inflated } \\
\text { Neg. Bin. }\end{array}$ & $\begin{array}{l}\text { GMM } \\
\text { Poisson }\end{array}$ & $\begin{array}{l}\text { Random } \\
\text { Effects } \\
\text { Poisson } \\
\end{array}$ & OLS \\
\hline $\mathrm{TF}$ & $-0.611 * * *$ & & & & & & & \\
\hline TF Differentiated & & $\begin{array}{l}-0.664 * * * \\
{[0.000]}\end{array}$ & $\begin{array}{l}-0.664 * * * \\
{[0.000]}\end{array}$ & $\begin{array}{l}-0.678 * * * \\
{[0.000]}\end{array}$ & $\begin{array}{l}-0.592^{* * *} \\
{[0.000]}\end{array}$ & $\begin{array}{l}-1.072 * * * \\
{[0.000]}\end{array}$ & $\begin{array}{l}-0.653 * * \\
{[0.035]}\end{array}$ & $\begin{array}{l}-0.676^{* * *} \\
{[0.000]}\end{array}$ \\
\hline TF Homogeneous & & $\begin{array}{l}-0.357^{* * *} \\
{[0.000]}\end{array}$ & $\begin{array}{l}-0.436^{* * *} \\
{[0.000]}\end{array}$ & $\begin{array}{l}-0.349 * * * \\
{[0.000]}\end{array}$ & $\begin{array}{l}-0.411^{* * *} \\
{[0.000]}\end{array}$ & $\begin{array}{l}-0.638^{* * *} \\
{[0.001]}\end{array}$ & $\begin{array}{l}-0.302 \\
{[0.314]}\end{array}$ & $\begin{array}{l}-0.182^{* * *} \\
{[0.005]}\end{array}$ \\
\hline Distance & $\begin{array}{l}-0.278^{* * *} \\
{[0.000]}\end{array}$ & $\begin{array}{l}-0.278^{* * *} \\
{[0.000]}\end{array}$ & $\begin{array}{l}-0.619 * * * \\
{[0.000]}\end{array}$ & $\begin{array}{l}-0.266^{* * *} \\
{[0.000]}\end{array}$ & $\begin{array}{l}-0.546 * * * \\
{[0.000]}\end{array}$ & $\begin{array}{l}-0.764^{* * *} \\
{[0.000]}\end{array}$ & $\begin{array}{l}-1.109 * * * \\
{[0.000]}\end{array}$ & $\begin{array}{l}-0.375^{* * *} \\
{[0.000]}\end{array}$ \\
\hline Common Border & $\begin{array}{l}1.093^{* * *} \\
{[0.000]}\end{array}$ & $\begin{array}{l}1.093^{* * *} \\
{[0.000]}\end{array}$ & $\begin{array}{l}1.391^{* * *} \\
{[0.000]}\end{array}$ & $\begin{array}{l}1.046^{* * *} \\
{[0.000]}\end{array}$ & $\begin{array}{l}1.294^{* * *} \\
{[0.000]}\end{array}$ & $\begin{array}{l}1.243^{* * *} \\
{[0.000]}\end{array}$ & $\begin{array}{l}0.878^{* * *} \\
{[0.000]}\end{array}$ & $\begin{array}{l}1.967^{* * *} \\
{[0.000]}\end{array}$ \\
\hline Shared Language & $\begin{array}{l}0.131 \\
{[0.361]}\end{array}$ & $\begin{array}{l}0.13 \\
{[0.362]}\end{array}$ & $\begin{array}{l}0.366^{* * *} \\
{[0.001]}\end{array}$ & $\begin{array}{l}0.127 \\
{[0.309]}\end{array}$ & $\begin{array}{l}0.420 * * * \\
{[0.000]}\end{array}$ & $\begin{array}{l}0.309 * * \\
{[0.019]}\end{array}$ & $\begin{array}{l}0.456^{* * *} \\
{[0.001]}\end{array}$ & $\begin{array}{l}0.418^{* * *} \\
{[0.000]}\end{array}$ \\
\hline Colonial History & $\begin{array}{l}0.589 * * * \\
{[0.000]}\end{array}$ & $\begin{array}{l}0.589 * * * \\
{[0.000]}\end{array}$ & $\begin{array}{l}0.789 * * * \\
{[0.000]}\end{array}$ & $\begin{array}{l}0.580 * * * \\
{[0.000]}\end{array}$ & $\begin{array}{l}0.680 * * * \\
{[0.000]}\end{array}$ & $\begin{array}{l}0.893 * * * \\
{[0.000]}\end{array}$ & $\begin{array}{l}0.381^{* * *} \\
{[0.000]}\end{array}$ & $\begin{array}{l}0.575^{* * *} \\
{[0.000]}\end{array}$ \\
\hline Landlocked & $\begin{array}{l}-0.403^{* * *} \\
{[0.000]}\end{array}$ & $\begin{array}{l}-0.406^{* * *} \\
{[0.000]}\end{array}$ & $\begin{array}{l}-0.024 \\
{[0.757]}\end{array}$ & $\begin{array}{l}-0.372^{* * *} \\
{[0.000]}\end{array}$ & $\begin{array}{l}-0.079 \\
{[0.305]}\end{array}$ & $\begin{array}{l}0.287 * * * \\
{[0.003]}\end{array}$ & $\begin{array}{l}0.093 \\
{[0.734]}\end{array}$ & $\begin{array}{l}-0.269 * * * \\
{[0.000]}\end{array}$ \\
\hline GDP & $\begin{array}{l}0.293 * * * \\
{[0.000]}\end{array}$ & $\begin{array}{l}0.292 * * * \\
{[0.000]}\end{array}$ & $\begin{array}{l}0.479 * * * \\
{[0.000]}\end{array}$ & $\begin{array}{l}0.277 * * * \\
{[0.000]}\end{array}$ & $\begin{array}{l}0.451^{* * *} \\
{[0.000]}\end{array}$ & $\begin{array}{l}0.490 * * * \\
{[0.000]}\end{array}$ & $\begin{array}{l}0.575^{* * *} \\
{[0.000]}\end{array}$ & $\begin{array}{l}0.379 * * * \\
{[0.000]}\end{array}$ \\
\hline Population & $\begin{array}{l}0.410 * * * \\
{[0.000]}\end{array}$ & $\begin{array}{l}0.410 * * * \\
{[0.000]}\end{array}$ & $\begin{array}{l}0.357 * * * \\
{[0.000]}\end{array}$ & $\begin{array}{l}0.410^{* * *} \\
{[0.000]}\end{array}$ & $\begin{array}{l}0.334 * * * \\
{[0.000]}\end{array}$ & $\begin{array}{l}0.415^{* * *} \\
{[0.000]}\end{array}$ & $\begin{array}{l}0.249 * * \\
{[0.010]}\end{array}$ & $\begin{array}{l}0.326 * * * \\
{[0.000]}\end{array}$ \\
\hline LDC & $\begin{array}{l}-0.696^{* * *} \\
{[0.000]}\end{array}$ & $\begin{array}{l}-0.696^{* * *} \\
{[0.000]}\end{array}$ & $\begin{array}{l}-0.719 * * * \\
{[0.000]}\end{array}$ & $\begin{array}{l}-0.591 * * * \\
{[0.000]}\end{array}$ & $\begin{array}{l}-0.496 * * * \\
{[0.000]}\end{array}$ & $\begin{array}{l}-0.868 * * * \\
{[0.000]}\end{array}$ & $\begin{array}{l}-0.586 * * * \\
{[0.007]}\end{array}$ & $\begin{array}{l}-0.573^{* * *} \\
{[0.000]}\end{array}$ \\
\hline EU Tariff & $\begin{array}{l}5.693 * * * \\
{[0.001]}\end{array}$ & $\begin{array}{l}5.693 * * * \\
{[0.001]}\end{array}$ & $\begin{array}{l}2.782^{* *} \\
{[0.017]}\end{array}$ & $\begin{array}{l}6.344 * * * \\
{[0.000]}\end{array}$ & $\begin{array}{l}5.373^{* * *} \\
{[0.000]}\end{array}$ & $\begin{array}{l}0.327 \\
{[0.786]}\end{array}$ & $\begin{array}{l}-3.394 * * \\
{[0.044]}\end{array}$ & $\begin{array}{l}5.226 * * * \\
{[0.000]}\end{array}$ \\
\hline Remoteness & $\begin{array}{l}0.763 \\
{[0.222]}\end{array}$ & $\begin{array}{l}0.767 \\
{[0.220]}\end{array}$ & $\begin{array}{l}0.955^{* * *} \\
{[0.007]}\end{array}$ & $\begin{array}{l}0.743 \\
{[0.172]}\end{array}$ & $\begin{array}{l}1.108^{* * *} \\
{[0.000]}\end{array}$ & $\begin{array}{l}0.810^{* *} \\
{[0.035]}\end{array}$ & $\begin{array}{l}2.966^{* *} \\
{[0.011]}\end{array}$ & $\begin{array}{l}1.989 * * * \\
{[0.000]}\end{array}$ \\
\hline Constant & $\begin{array}{l}-6.658 * * * \\
{[0.000]}\end{array}$ & $\begin{array}{l}-7.464^{* * *} \\
{[0.000]}\end{array}$ & $\begin{array}{l}-8.039 * * * \\
{[0.000]}\end{array}$ & $\begin{array}{l}-7.192^{* * *} \\
{[0.000]}\end{array}$ & $\begin{array}{l}-7.886^{* * *} \\
{[0.000]}\end{array}$ & $\begin{array}{l}-7.159 * * * \\
{[0.000]}\end{array}$ & $\begin{array}{l}-4.438 * * * \\
{[0.005]}\end{array}$ & $\begin{array}{l}-8.449 * * * \\
{[0.000]}\end{array}$ \\
\hline No. of Observations & 6250 & 6250 & 6250 & 6250 & 6250 & 6250 & 6250 & 4380 \\
\hline Importer Effects & Yes & Yes & Yes & Yes & Yes & Yes & Yes & Yes \\
\hline Type Effects & Yes & Yes & Yes & Yes & Yes & Yes & Yes & Yes \\
\hline
\end{tabular}


Table 8. Robustness: Sample and Covariates

\begin{tabular}{|c|c|c|c|c|c|c|c|c|c|}
\hline & Products $>0$ & Products $>10$ & Products $>50$ & Corruption & Market Entry & Agriculture & RCA_Agr & RCA_Min & Income Class \\
\hline \multirow[t]{2}{*}{ TF Differentiated } & $-0.680 * * *$ & $-0.684 * * *$ & $-0.657 * * *$ & $-0.639 * * *$ & $-0.621 * * *$ & $-0.669 * * *$ & $-0.611 * * *$ & $-0.504 * * *$ & \\
\hline & {$[0.000]$} & {$[0.000]$} & {$[0.000]$} & {$[0.000]$} & {$[0.000]$} & {$[0.000]$} & {$[0.000]$} & {$[0.000]$} & \\
\hline \multirow[t]{2}{*}{ Low Income } & & & & & & & & & $-0.659 * * *$ \\
\hline & & & & & & & & & {$[0.000]$} \\
\hline \multirow[t]{2}{*}{ Middle/High Income } & & & & & & & & & $-0.600 * * *$ \\
\hline & & & & & & & & & {$[0.000]$} \\
\hline \multirow[t]{2}{*}{ TF Homogeneous } & $-0.347 * * *$ & $-0.369 * * *$ & $-0.465^{* * *}$ & $-0.326 * * *$ & $-0.311^{* * *}$ & $-0.332 * * *$ & $-0.294 * * *$ & $-0.197 * *$ & \\
\hline & {$[0.000]$} & {$[0.000]$} & {$[0.000]$} & {$[0.000]$} & {$[0.000]$} & {$[0.000]$} & {$[0.000]$} & {$[0.016]$} & \\
\hline \multirow[t]{2}{*}{ Low Income } & & & & & & & & & $-0.279 * * *$ \\
\hline & & & & & & & & & {$[0.000]$} \\
\hline \multirow[t]{2}{*}{ Middle/High Income } & & & & & & & & & $-0.161 *$ \\
\hline & & & & & & & & & {$[0.053]$} \\
\hline \multirow[t]{2}{*}{ Distance } & $-0.265 * * *$ & $-0.239 * * *$ & $-0.207 * * *$ & $-0.294 * * *$ & $-0.226 * * *$ & $-0.293 * * *$ & $-0.446 * * *$ & $-0.387 * * *$ & $-0.265^{* * *}$ \\
\hline & {$[0.000]$} & {$[0.000]$} & {$[0.000]$} & {$[0.000]$} & {$[0.001]$} & {$[0.000]$} & {$[0.000]$} & {$[0.000]$} & {$[0.000]$} \\
\hline \multirow[t]{2}{*}{ Common Border } & $1.047 * * *$ & $0.912^{* * *}$ & $0.698^{* * *}$ & $1.450^{* * *}$ & $1.012^{* * *}$ & $0.980^{* * *}$ & $1.046^{* * *}$ & $1.017 * * *$ & $1.036^{* * *}$ \\
\hline & {$[0.000]$} & {$[0.000]$} & {$[0.002]$} & {$[0.000]$} & {$[0.000]$} & {$[0.000]$} & {$[0.000]$} & {$[0.000]$} & {$[0.000]$} \\
\hline \multirow[t]{2}{*}{ Shared Language } & 0.127 & 0.083 & 0.021 & 0.129 & 0.143 & 0.118 & 0.082 & 0.074 & 0.172 \\
\hline & {$[0.362]$} & {$[0.532]$} & {$[0.874]$} & [0.331] & {$[0.304]$} & {$[0.404]$} & {$[0.563]$} & {$[0.601]$} & {$[0.225]$} \\
\hline \multirow[t]{2}{*}{ Colonial History } & $0.579 * * *$ & $0.563^{* * *}$ & $0.533 * * *$ & $0.550^{* * *}$ & $0.617^{* * *}$ & $0.592 * * *$ & $0.606^{* * *}$ & $0.611^{* * *}$ & $0.589 * * *$ \\
\hline & {$[0.000]$} & {$[0.000]$} & {$[0.000]$} & {$[0.000]$} & {$[0.000]$} & {$[0.000]$} & {$[0.000]$} & {$[0.000]$} & {$[0.000]$} \\
\hline \multirow[t]{2}{*}{ Landlocked } & $-0.370 * * *$ & $-0.213^{* *}$ & 0.036 & $-0.406^{* * *}$ & $-0.512^{* * *}$ & $-0.419 * * *$ & $-0.378 * * *$ & $-0.403^{* * *}$ & $-0.438 * * *$ \\
\hline & {$[0.000]$} & {$[0.015]$} & {$[0.766]$} & {$[0.000]$} & {$[0.000]$} & {$[0.000]$} & {$[0.000]$} & {$[0.000]$} & {$[0.000]$} \\
\hline \multirow[t]{2}{*}{ GDP } & $0.276^{* * *}$ & $0.235^{* * *}$ & $0.185^{* * *}$ & $0.108^{* * *}$ & $0.225^{* * *}$ & $0.379 * * *$ & $0.384 * * *$ & $0.400^{* * *}$ & $0.244^{* * *}$ \\
\hline & {$[0.000]$} & {$[0.000]$} & {$[0.000]$} & {$[0.001]$} & {$[0.000]$} & {$[0.000]$} & {$[0.000]$} & {$[0.000]$} & {$[0.000]$} \\
\hline \multirow[t]{2}{*}{ Population } & $0.410^{* * *}$ & $0.405^{* * *}$ & $0.382 * * *$ & $0.601^{* * *}$ & $0.458^{* * *}$ & $0.317^{* * *}$ & $0.313^{* * *}$ & $0.367 * * *$ & $0.461^{* * *}$ \\
\hline & {$[0.000]$} & {$[0.000]$} & {$[0.000]$} & {$[0.000]$} & {$[0.000]$} & {$[0.000]$} & {$[0.000]$} & {$[0.000]$} & {$[0.000]$} \\
\hline \multirow[t]{2}{*}{ LDC } & $-0.588 * * *$ & $-0.419 * * *$ & $-0.220 * *$ & $-0.740 * * *$ & $-0.572 * * *$ & $-0.554 * * *$ & $-0.502 * * *$ & $-0.824 * * *$ & $-0.619 * * *$ \\
\hline & {$[0.000]$} & {$[0.000]$} & {$[0.046]$} & {$[0.000]$} & {$[0.000]$} & {$[0.000]$} & {$[0.000]$} & {$[0.000]$} & {$[0.000]$} \\
\hline \multirow[t]{2}{*}{ EU Tariff } & $6.340^{* * *}$ & $7.094^{* * *}$ & $7.360^{* * *}$ & $3.711^{* *}$ & $5.755^{* * *}$ & $6.248^{* * *}$ & $4.994 * * *$ & $5.372^{* * *}$ & $5.874 * * *$ \\
\hline & {$[0.001]$} & {$[0.000]$} & {$[0.000]$} & {$[0.022]$} & {$[0.001]$} & {$[0.001]$} & {$[0.004]$} & {$[0.002]$} & [0.001] \\
\hline Remoteness & 0.744 & 0.51 & 0.032 & 0.351 & 0.28 & 0.888 & -0.202 & $1.051^{*}$ & 0.781 \\
\hline
\end{tabular}




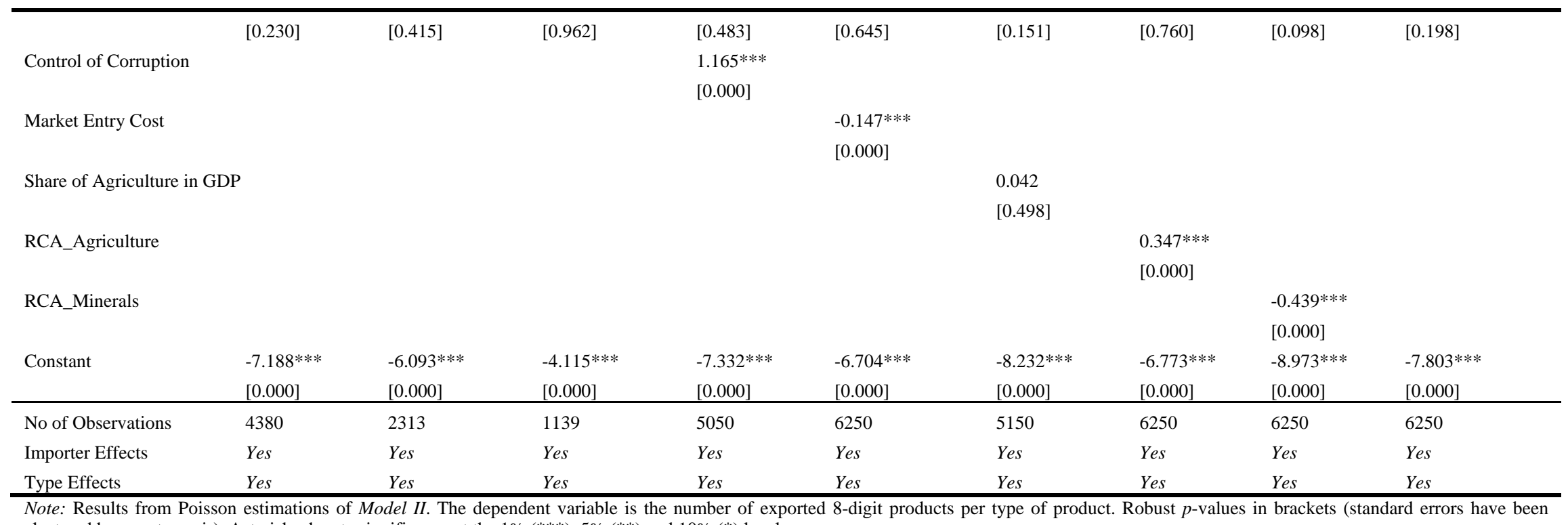

clustered by country-pair). Asterisks denote significance at the $1 \%\left({ }^{* * *}\right), 5 \%\left({ }^{* *}\right)$ and $10 \%\left({ }^{*}\right)$ levels. 